\title{
From Exotics to Brainwashers: Portraying New Religions in Mass Media
}

Sean McCloud*

The University of North Carolina at Charlotte

\begin{abstract}
This essay examines how American magazines have portrayed new religions since the World War II. Media depictions have changed dramatically from the 1950s to the present. Specifically, journalists in the 1950s and early 1960s used the dual Cold War themes of exoticism and subversion to depict new religions. In the late 1960s and early 1970s, subjects and themes began to change. Newsmagazines ambivalently reported on the gurus, Asian new religions, and occult spirituality attracting some in the burgeoning youth counterculture with a mixture of exoticism and wariness. By the mid-1970s, media images became more ominous. News, general interest, and entertainment media represented new religions as a growing "cult menace" and highlighted the dangers that brainwashing groups posed to unsuspecting followers. The 1978 Jonestown mass suicide seemed to confirm such negative cult stereotypes, leading to homogenous portrayals of new religions that continued through the 1990s. In explaining such changes over time, the essay ends by proposing five complimentary theses for understanding late-twentieth-century mass media representations of new religions.
\end{abstract}

\section{Introduction}

In 1959 Look magazine featured a pictorial of a religious commune called the Wisdom, Knowledge, Faith and Love Fountain of the World (WKFL). The article was titled "California's Offbeat Religions: 'We Love You.'" The photo-essay included eight pictures of the group. The first showed members standing in the dark, holding candles, clothed in long robes, and staring grimly at the camera. In successive shots we saw members hugging, a novitiate receiving a blood test, and one member holding two children. The final page featured three photographs of a woman identified as "Bishop Mary.' In all three she was shown performing an improvisational dance to classical music. "Like Bishop Mary," one caption read, "all Fountain members are "creativity-conscious'" (Brossard 1959, 102). After the initial ominous photograph, the commune appeared colorfully offbeat. Look's pictorial and accompanying words made the group appear more theatrical than solemn, and the magazine's frame did not suggest it was controversial - let alone dangerous. 
This is striking, because the group was steeped in controversy and violence. Krishna Venta, the commune's founder, was killed in 1958 when two disgruntled male followers blew him up with twenty sticks of dynamite. These apostates accused Venta of illicit sexual relations with female members, including underage girls (Mathison 1960). But national magazine coverage, both before and after Venta's murder, played down these seamy details. A few articles failed to even mention the specific charges against the founder. Look, whose feature on the commune appeared eight months after Venta's death, only noted that he "was dynamited to bits in his office last year by two members who felt he was guilty of malpractices" (Brossard 1959, 101). While many magazine writers did detail accusations against Venta, their tone was often more satirical than critical or foreboding. In the Look article, for example, Chandler Brossard recounted the charges with humor and concluded that the post-Venta WKFL was "a bit bemused, but entirely impressive and loveable" (Brossard 1959, 101).

Contrast the 1950s coverage of WKFL and Krishna Venta with the 1990s treatment of the Branch Davidians and their prophetic leader David Koresh. On April 19, 1993, the Branch Davidian commune outside Waco, Texas, burned to the ground with 74 people inside. This tragedy entailed the ending of a fifty-one day standoff between the Davidians and agents from the FBI and the Bureau of Alcohol,Tobacco, and Firearms, which had unsuccessfully attempted to raid the commune on February 28 under suspicion that the religious group was stockpiling illegal guns. From the beginning of the standoff, newspaper, magazine, and television journalists described Koresh, in Time's words, as a "preacherly hypnotist" who brainwashed his hapless followers (Morrow 1993, 34). Koresh, like Venta, was accused of having illicit relations with a number of women in the group, including fourteenyear-old girls. And also like Venta, these accusations were confirmed by members. Rumors of child abuse within the Davidian commune also circulated. But unlike the 1950s and 1960s stories, journalists reporting on these events framed them as moral atrocities and Koresh as a dangerous deviant. What accounts for this dramatic difference in coverage?

In the last thirty years, the word "cult," today's most common mass media moniker for new religions, has lost any descriptive, sociological meaning it may have once had. It now conjures images of brainwashing, coercion, deception, exploitation, perversion, and religious fraud. For many Americans these associations have become doxa - those socially constructed opinions, assumptions, and inclinations so taken for granted that they seem natural. Such associations have been particularly strong in American news media. (Richardson and van Driel 1997; Shupe 1997; Wright 1997) According to many scholars, the associations between new religions and the "cult menace" are largely due to the "Anti-Cult Movement" (ACM), a loosely organized group of parents, psychiatrists, and clergy who throughout the 1970s to the 1990 s lobbied various governments and went to court to legally restrict the activities of many new religious movements. Some even kidnapped their 
sons and daughters to remove them from certain religions. (Bromley and Shupe 1980; Beckford 1999; Melton 1999; Shupe and Bromley 1994) One scholar credits the ACM with creating the category "cult" and suggests that "print and broadcast media for the most part uncritically accepted the ACM's analysis" of new religions (Greil 1996, 56-57; see also Richardson 1993).

While the ACM certainly played a role in the increasingly negative media coverage of new religions, here I argue that the development of the "cult menace" motifs that dominated coverage of Koresh and the Branch Davidians was also part of a larger historical shift in journalistic discourses about American "mainstream" and "fringe" religions. In other words, the way national journalists portrayed, or "framed," new religions changed over time in ways that led to increasingly ominous portrayals. Specifically, I argue that national print media depictions of the American religious fringe changed significantly from the 1950s to the early 1990s (McCloud 2004). I suggest three distinct periods. First, in the Cold War '50s and '60s, the most prominent fringe portrayals focused on working-class white and African American groups, as well as certain religions prominent in California. In a period marked by the rhetoric of an American cultural consensus set against "Godless communism," periodicals such as Time, Newsweek, U.S. News and World Report, Saturday Evening Post, Life, and Look reported on the "California cults" and other groups such as the Nation of Islam, using themes of mass movements, exoticism, and subversion.

In the second period, from the late 1960s through early 1970s, subjects and themes changed. Cold War consensus ideology yielded to growing recognition of cultural diversity spurred by the civil rights and youth counterculture movements. At the same time, magazine coverage ambivalently framed the gurus, Asian new religions, occult spirituality, and Evangelical Jesus movements attracting white, middle- and upper-middle-class youth. Eventually, coverage would also feature the grievances of a growing "anticult movement" made up of parents who wanted to remove their adult children from these groups.

In the third period, beginning in the mid-1970s, journalistic images of the fringe darkened. Magazines like Newsweek, McCall's, and Reader's Digest promoted the image of a growing cult menace by highlighting the dangers that dictatorial leaders of fringe groups posed to unsuspecting mainstream individuals through brainwashing and coercion. The 1978 Jonestown mass suicide seemed to confirm the negative stereotypes and led to homogenous portrayals in a variety of magazines. By 1993, this "cult menace" motif had become so thoroughly inscribed in many magazine narratives that it dominated news stories about the fifty-one-day Branch Davidian/FBI standoff in Waco.

In what follows, I do three things. First, I trace these three periods. Second, I point to the recent media "mainstreaming" of a particular new religion, Neopaganism. Third, I propose five complimentary theses for understanding late-twentieth-century mass media representations of new religions. 
In the 1950s and early 1960s, the largest news and general interest periodicals consistently used two somewhat contradictory themes to depict new religions and other groups they dubbed marginal or offbeat. First, they portrayed the religious periphery as exotic - weird, colorful, and mysterious - yet mostly harmless. Second, and more ambivalently, writers and editors depicted certain new religious movements as zealous, emotional, dogmatic, and potentially subversive. Magazine writers suggested that the high levels of commitment, enthusiasm, and exoticism characteristic of these groups were excessive, even "unhealthy." Media portrayals occasionally implied that certain new religions were un-American, and raised specters of foreignness and Communism when discussing certain groups.

Labeling something "exotic" is a crucial step in identifying its opposite, the domestic - that constituted as "normal" and "everyday." During the 1950s and early 1960s, the boundaries between exotic/domestic and mainstream/fringe religions were in flux. Depicting certain religious groups - or more accurately, the characteristics of certain groups - as marginal established new boundaries around a changing, vaguely defined conception of "mainstream." One place journalists associated with exotic new religions was California. Even though many of California's so-called "cults" were well established outside the state, journalists in the largest periodicals - who were overwhelmingly based in the northeast - consistently associated California with exotic spirituality. For example, the subtitle of Louie Robinson's 1963 Ebony article, "The Kingdom of King Narcisse," read "California breeds another bizarre but colorful sect" (112). Similarly, in 1956, Newsweek published "The Way of the Cults." The story focused on the numerous "sects in the Los Angeles area which can best - or most conservatively - be described as odd-looking to almost anybody who does not live in southern California" "Way of the Cults" 1956, 102). The unnamed authors dubbed California the "cult center of the United States" and offered several explanations. "One theory," Newsweek wrote, "is that cults attract the elderly, and so does California" ("Way of the Cults" 1956, 102). Other reasons included the ease with which religions could gain legal status in the state, the Los Angeles area's responsiveness to the colorful, and the particularly deep emotional needs and gullibility of the city's citizens. The writers briefly described several groups, including the Self-Realization Fellowship, Theosophical Society, Vedanta Society, and Aimee Semple McPherson's Pentecostal Four-Square Gospel Church. "Some of these movements may strike the viewer-from-afar as positively odd," Newsweek concluded, "yet Los Angeles has proven that oddity, as some may call it, can attract wide and devoted followings" ("Way of the Cults" 1956, 105).

But new religious depictions during the Cold War could also be ominous, and the best example of this can be seen in coverage of the Nation of Islam. News periodicals suggested that the Nation - an African American new 
religion founded in 1930 that combined orthodox Muslim practices, Evangelical Protestantism, and the new revelations and teachings of W. D. Fard and the Honorable Elijah Muhammad - posed a subversive threat to the United States. For example, in 1959 U.S. News and World Report published a feature article entitled " 'Black Supremacy' Cult in U.S. - How Much of a Threat?" Answering this question, the anonymous writers asserted that the group had no apparent Communist or foreign connections, but could still pose a "foreign-like" threat to the nation. "In time of war," they concluded, "the Muslims could present a major problem: they are taught they owe allegiance only to the flag of Islam" (" "Black Supremacy' Cult in U.S." 1959, 114). For reasons of "civic safety" and "national security," U.S. News reassured, federal and local authorities - and presumably the newsmagazine itself - would continue to keep "close tabs on the strength and influence of this 'Black Supremacy' movement" (" 'Black Supremacy' Cult in U.S." 1959, 114).

Historian Tom Englehardt suggests that "a nightmarish search for enemy-ness became the defining, even obsessive domestic act of the Cold War years" (1995, 7). But Communism, he argues, proved a "bedeviling" foe to pinpoint because "it was never fully identified with or contained within any single ethnic or racial community" (99). For white journalists, however, the all-black Nation of Islam (NOI) served as an easily recognizable Cold War enemy. The racial make-up of the lower-class NOI had them fearing imminent revolt, and fears about the "Black Muslims" were almost always articulated in the language of possibilities. Police chiefs told journalists that the group could cause problems in inner cities. Journalists told readers the movement might be a war-time threat because they could potentially be used by Communists, Arabs, or some unidentified foreign enemies. At the heart of stories about the Nation of Islam was distancing and ambiguity: because we don't know what they are capable of, we fear them.

\section{From exotics to dangerous deviants, 1966-72}

The period from the mid-1960s through the mid-1970s saw the beginnings of the gradual shift in fringe and new religious movement representations from disdained exotics and potential subversives to inherently dangerous deviants. Political assassinations, the Vietnam War and its atrocities, race riots, an energy crisis, the Watergate scandal, and the civil rights and countercultural movements marked the period as one in which the image of a unified American cultural consensus seemed increasingly distant. In addition to covering and commenting on these social upheavals, magazines responded to concern over a growing generation gap, a vocal youth counterculture, and an apparent (although perhaps statistically unfounded) "cult explosion" by turning their attention away from groups such as the "California cults" and the Nation of Islam. Instead, they increasingly focused on the guru-based Asian religions, Evangelical Jesus Movements, and Occult 
practices that were attracting predominantly white, middle- and upper-middleclass youth.

In this same period, journalistic representations of new and alternative religions darkened. This can be seen in changing coverage of occult new religions and the Jesus Movement. For example, in 1966 the Saturday Evening Post featured John Kobler's essay, "Out for a Night at the Local Caldron." "To her neighbors," Kobler began, "Mrs. Eunice Jenkins (as we will call her, to avoid alarming them) is a plump, cheerful London housewife who ex-emplifies middle-class, middle-aged British decorum. But at the approach of Halloween, she prepares to perform some of the most bizarre pagan rites to have survived into the 20th century" (Kobler 1966, 76). The article was about British Neopagan Wicca, an eclectic occult religious movement made up of loosely connected groups and individuals who look to nature-oriented, often polytheistic religions and myths for inspiration. Kobler gave a history of the movement and its founder, Gerald Gardner. Kobler also interviewed practicing witches like Sybil Leek and Doreen Valiente. Throughout, he framed the British witches as curiosities who were simultaneously exotic and harmlessly domestic.

Contrast Kobler's piece to early 1970s stories in Time and Newsweek suggesting that dangerous - even murderous - Satanic groups lurked about the landscape ("Cult of the Occult"1970; "The Occult: A Substitute Faith" 1972). Such assertions were based more on rumor and supposition than any material evidence. But inclusion of these phantom-like Satanists in occult stories served to darken depictions of the periphery, adding dangerous deviancy to new religion reporting (Lippert 1990; Victor 1993).

Initially, and like early stories on the occult, the largest news and general interest magazines portrayed the Jesus Movement favorably. In a June 1971 cover story, Time concluded that "in a world filled with real and fancied demons for the young, the form their faith takes may be less important than the fact that they have it" ("New Rebel Cry 1971:63), U.S. News and World Report and Reader's Digest concurred. But such coverage changed when vocal parents expressed more negative views, and these views appeared in news media. In the late summer of 1971, William Rambur, a retired navy officer from California, started "The Parent's Committee to Free Our Sons and Daughters from the Children of God" after his daughter, a 22-year-old nursing student, joined the apocalyptic Children of God commune. By the late 1970s, this small parent's group would grow into a loosely organized national coalition of parents, pastors, and psychiatrists who lobbied against "cults."

This Anti-Cult Movement eventually provided a new and dramatic set of idioms for journalists writing about the American religious fringe.

\section{The cult menace, 1973-93}

In 1975, Time published a story about parents who were disgruntled over their children's membership in Sun Myung Moon's Unification Church. 
"Around the country," Time wrote, "hundreds of parents have been driven to near hysteria by changes in their convert children's behavior and by reports of brainwashing" ("Mad About Moon" 1975, 44). Supporting parents' fears, the newsmagazine noted that both ex-members and psychologists confirmed the brainwashing allegations. Today, the overwhelming majority of psychologists, sociologists, and religion scholars not only repudiate charges of brainwashing leveled against new religions, they question whether such an activity even exists (Bromley and Richardson 1983; Robbins 1984; Richardson 1994; Dawson 1998). Rather than describing an actual process, they suggest, "brainwashing" is more accurately viewed as a rhetorical term that negatively marks certain religions the speaker doesn't like. Although critics of brainwashing were even vocal in the 1970s, the period's journalists selectively quoted "experts" and used the concept as if it were an undisputed scientific fact. Time, for example, quoted one defector's charges of "psychological abuse" and "subliminal fascism," and further reported that "Harvard Psychiatrist John Clark Jr. recently testified in District of Columbia Superior Court that the ex-Moonies he had examined seemed physically and emotionally exhausted; a few were psychotic" ("Mad About Moon" 1975, 44). The story ended portentously, noting that "Jack Kerry, the Moon watcher in the California attorney general's office, sees the movement as 'extremely dangerous' and adds: 'I think this whole situation is going to explode" ("Mad About Moon" 1975, 44).

The Unification Church, a new religion combining aspects of Christianity with the revelations and biblical interpretations of its founder Reverend Sun Myung Moon, was the archetypal cult of 1970s print media. Founded in Korea in 1954, the group, whose full name is the Holy Spirit Association for the Unification of World Christianity, attracted negative attention from some convert relatives and mass media in the United States for its aggressive proselytizing, totalistic communal living, and large group weddings. Various stripes of Christians and Jews also attacked Moon's revelatory scripture, The Divine Principle, as heretical. Sociologist Anson Shupe suggests that "the Unification Church, among all other new religious movements or 'cults,' has always been the bête noire of the modern anticult movement in America," adding that it "offers a veritable archetype of the dimensions that offend, infuriate, and threaten conventional society, thereby calling down accusations of heresy and setting in motion the ritual process of assigning the label 'evil'" (Shupe 1987, 207). Along with brainwashing motifs, journalists blended tenuous allegations of deviant sex rituals and conspiratorial foreign connections with documented cases of deceptive California proselytizing and Moon's antagonistic preaching to make captivating - if not alarming reading.

But the content of Unification Church coverage was not unique for its time. By the mid-1970s, charges of brainwashing, deception, fraud, and various improprieties appeared in most stories about groups journalists labeled 
cults. During this time, Reader's Digest explained "How Cults Bilk All of Us" and detailed a "Rescue from a Fanatic Cult." Parent's Magazine asked "Could Your Child be Brainwashed?" while U.S. News and World Report dared look "Behind the Cult Craze." By the late 1970s the connections between cults, brainwashing, and fraudulence had become naturalized. In other words, these associations became unquestioned truths in magazine articles and for many Americans.

Despite their ambivalence and occasional hostility toward new religions, both newsmagazines and religious periodicals in the mid-1970s denounced deprogramming - the act of forcibly removing an individual from his or her religious group - as a civil rights violation. For both "secular" and religious journalists, neither zealotry nor doctrinal heresy constituted grounds to violate an individual's religious liberty. But some special and general interest magazines - particularly family-oriented "homemaker" periodicals like Good Housekeeping, McCall's, and Reader's Digest - took the opposite view. These journals, recounting parents' heroic rescues and deprogrammings of their cult-victimized children, foreshadowed the cult menace frames that all magazine genres would utilize after the 1978 Jonestown mass suicide.

\section{JONESTOWN}

The Peoples Temple history has been well documented in several useful works, and I will only briefly outline it here (Hall 1987; Chidester 1988; Maaga 1998). The church was founded by James Warren Jones in Indiana in 1956. In 1960, the group formally joined the Disciples of Christ denomination. The early Peoples Temple stressed interracial worship and civil rights. As the head minister, Jones also practiced faith healing. In 1965, Jones moved the church to California, partly because he feared nuclear war and had read that the state's Redlands area was one place that might be spared from nuclear fallout. By the mid-1970s, the church was at an all-time high of between 5,000 to 7,000 members, with over sixty percent of the congregation African American. In 1975, Jones received positive endorsements from San Francisco's mayor for humanitarian work. In 1977, he received the Martin Luther King Jr. Humanitarian Award. With the exception of a few apostates, few even noticed the Peoples Temple, let alone saw it as a cultic threat.

During the mid-1970s, Jones developed the idea of a farming commune in the South American jungles of Guyana. Believing that U.S. society was too racist and classist, Jones sent the first church members to Guyana in 1975 to create Jonestown. Jones moved there in 1977. In 1978, pushed by the concern of church members' relatives, Congressman Leo Ryan decided to visit the commune. On his way back to the jungle airport, Ryan and some of his entourage were murdered by Peoples Temple assassins. Convinced that the U.S. military would respond by invading Jonestown, Jones and a small group of his assistants decided that the whole community should 
commit suicide. Jones had preached "revolutionary suicide," killing oneself to protest the world's injustice, for years. Jonestown members regularly conducted mass suicide drills known as "white nights." On November 18, 1978 , it wasn't a drill.

On December 4, 1978, Time, Newsweek, and U.S. News and World Report published nearly identical stories on the mass suicide. Both Time and Newsweek titled their covers "Cult of Death" and featured only slightly different photos of Jonestown's dead. All three suggested that Jim Jones used brainwashing to coerce his followers into committing suicide. Jonestown coverage in the largest newsweeklies was both monolithic and striking in its indictment of cults. Religious periodicals such as America, Christian Century, and Christianity Today similarly explained the tragedy in terms of brainwashing. Sociologist Eileen Barker has shown that Jonestown proved to be the watershed event that made new religions synonymous with the cult menace (Barker 1986). The zealous exotics in Cold War mass movements had transformed into dangerous, brainwashing criminals. The negative associations with the term cult had become assumed and thus unquestioned. It was the cult menace motifs of brainwashing, exploitation, fraud, and psychological instability that made up the difference between the 1950s coverage of Krishna Venta and the WKFL and David Koresh and the Branch Davidians in 1993.

Similar to Jonestown, the Branch Davidian tragedy had the immediate effect of giving anticult groups such as the Cult Awareness Network (CAN) a public voice through mass media outlets. But by mid-May 1993 - only a month later - the Waco incident had virtually disappeared from the airwaves and newsstands. When it returned in a few summer and fall follow-ups, the journalistic portrayal of it had changed. Instead of telling the all-too familiar story of a maniacal cult leader who had brainwashed his followers and lead them to death, the new stories suggested government culpability for the standoff's violent ending. Instead of featuring anticultists telling readers what "cults" do, magazines such as Newsweek turned to religious studies scholars for commentary. In some ways, the Waco incident was the peak of the gradually declining influence of the Anti-Cult Movement in American mass media.

\section{"Mainstreaming" new religions?}

The period from the late 1970s to the present witnessed the tragedies of the 1978 Jonestown mass suicide, the 1993 Branch Davidian conflagration, the 1994 Solar Temple murder-suicides, the 1995 nerve gas attack on the Tokyo subway by Aum Shinrikyo, and the 1997 mass suicide of the members of Heaven's Gate. In part, the period from 1978 to present could be narrated through a series of so-called "cult controversies" in which a loosely organized Anti-Cult Movement charged certain new religions with brainwashing and fought to impose legal restrictions on them. But at the same time, the period 
saw the growing media acceptance of new religions such as Mormonism and Neopaganism.

For example, an article appearing on the Religion Newswriter's Association's “Tips” webpage for journalists on October 11, 2004, was titled "Wicca Moves into the Mainstream." The report described how Wicca, the largest branch of Neopaganism, had grown dramatically since the 1960s and offered reporters a number of practitioners, academics, and other contacts. While the "mainstreaming" of Wicca and Neopaganism suggested in the article might have been uneven in different regions of the country, the story was certainly supported in the marketplace of American popular culture, where positive images of Wiccans were appearing on the shelves of chain bookstores, in movies, and in children's shows such as Cartoon Network's New Scooby Doo and Disney's W.I.T.C.H. series. How other new religions currently fare in American mass media, and whether the future will hold further "mainstreaming" of particular groups, are two pertinent questions for interested researchers to pursue.

\section{Five theses for understanding mass media representations of new religions}

So why have the journalistic accounts of new religions provided by mass market magazines in the United States developed in this way? It appears that there are at least five factors that should be taken into consideration.

1. Journalists tapped into some longstanding debates in American religious history.

Throughout the last fifty years, the largest news and general interest magazines consistently dubbed new religious groups "fringe" that demonstrated high levels of religious zeal, dogma, and emotion. Labeling certain religious practices and beliefs marginal, writers and editors in the largest news and general interest magazines broached long-standing debates in American religious history about emotional versus rational religion, exotic versus familiar spirituality, and normal versus abnormal levels of piety. Journalists acted as "heresiographers," identifying false or inauthentic religion and thus symbolically establishing boundaries between a mainstream religious center and a suspect periphery.

That journalists did this should not be surprising. Throughout American history, clerics, journalists, politicians, and historians have labeled certain religious movements as central or peripheral to national and religious purposes. Take, for example, the antebellum debates over the compatibility of Roman Catholicism to American ideals. Nativists like Samuel Morse asserted that Catholic immigrants, because of their allegiance to the Pope, posed an imminent threat to American democracy. On the other side of the debate stood Catholics like convert Orestes Brownson, who suggested that Catholicism was the religion actually best suited for the United States (Gaustad 1993). In a country where the Constitution prohibits a state-sanctioned 
church, insider/outsider and orthodox/heretical classifications have often acted as a strategic substitute for socially and politically legitimating some groups and de-legitimizing others. Over the past four centuries, Catholics, Shakers, Mormons, Jehovah's Witnesses, and others have been labeled heretical, cultic, and un-American. Scholars note that all of these groups have been subject to similar macabre and frequently unsubstantiated tales that linked them with licentiousness, kidnapping, conspiracy, and even murder (Davis 1960; Cox 1978; Bromley and Shupe 1981).

2. Cold war depictions of new religions reproduced and legitimized the race/class inequalities of American society.

The largest 1950s and early 1960s news and general interest magazines often labeled religious groups mainstream or fringe in ways that symbolically reproduced and legitimized inequalities of race and class in postwar America. Relegating particular groups, activities, and beliefs to the religious margins, journalists concomitantly banished certain classes and racial groups to America's social periphery. In other words, writers and editors in periodicals like Time, Newsweek, and Life frequently offered, under the guise of objective reporting, a spiritual apologetics for the dominant social order. Overall, and in several ways, such magazines assumed a normative American mainstream that was white, upper-middle and middle-class, male, and religiously liberal or non-affiliated. In presupposing this, they sometimes distinguished religious fringe and mainstream by class and race as much as theology or movement size. Perhaps unsurprising, these periodicals generalized and normalized the perspectives and concerns of the very groups from which surveys tell us the vast majority of these magazines' journalists and readers came.

3. The changing portrayals of new religions related to changes in the broader culture and the media industry.

Changes in coverage of new religions coincided with larger social, cultural, and magazine industry changes. Socially, the 1950s to the 1990s saw increasing racial, ethnic, and religious diversity. The United States simultaneously witnessed an ideological move from a Cold War consensus culture to one in which pluralism and difference became a significant, and widely accepted, part of public discourse. Interestingly, media scholar A. J. van Zuilen notes that the magazine industry reflected this shift. General interest magazines like Life, Look, and Saturday Evening Post, which strove to speak to and for all Americans, either declined or disappeared by the early 1970s. During the same period, special interest consumer magazines, made to appeal to niche markets divided by race, gender, age, profession, and hobby interests, came to dominate the industry (van Zuilen 1977).

By the latter 1970s and 1980s, newsmagazines were spurred by corporate conglomeration and for-profit publishing - not to mention the success of investigative reporting in uncovering the Nixon White House Watergate scandal - to increase both their shock exposé and human interest features. 
Incidents like Jonestown and the court battles between deprogrammers and new religions took up not only religion sections, but cover stories. One result of this was what van Driel and Richardson call the "stream of controversies approach" to new religious movement reporting (Van Driel and Richardson 1988).

4. Mass media depictions of new religions must be understood partly as a product of the social locations of journalists.

American new and sectarian religions functioned for journalists as "negative reference groups" in a process of identity construction. In other words, the "cultic margins" of American religion helped define what writers and editors either desired or perceived themselves, their readers, and U.S. culture as a whole to be. But journalistic depictions did not always speak with one voice. The national print media is best viewed as a contested arena of symbolic production where various magazines categorize groups as mainstream/marginal, orthodox/heterodox, or religious/non-religious in ways that accord with the social locations of their producers. Mainstream and fringe and "cult" and "religion" are constructed and contested categories that are constantly in flux, reflecting certain interests, concerns, and power positions. For example, magazines that placed theological considerations before economic, political, or racial ones - like Christianity Today, written by and for conservative Evangelicals, or America, a Catholic Jesuit periodical - sometimes offered mainstream/fringe categorizations that questioned the overwhelmingly similar portrayals found in U.S. News and World Report, Time, Life, Newsweek, Reader's Digest, and Esquire. Likewise, magazines geared toward African Americans, like Jet, held different assumptions and concerns and thus depicted groups such as the Nation of Islam very differently than U.S. News and World Report or Time. In addition to divergent depictions in large African American, Catholic, and Evangelical magazines, small religious groups like the International Society of Krishna Consciousness (also known as "Hare Krishnas") and the Nation of Islam published their own periodicals and pamphlets. These also offered alternatives to the dominant media representations. Like the black newspapers in communications scholar Ronald Jacobs's study of urban unrest coverage, these media sites - created by groups labeled fringe - offered "a place for counteracting the effects of (in this case representational) hegemony, by constructing alternative narratives" about themselves and the so-called mainstream religions. (Jacobs 2000, 28)

5. What journalists wanted readers "to get" in new religion reporting was not necessarily what readers took from it.

Writers and editors framed new religion stories and accompanying photos in ways that suggested which topics were most important and who the "heroes" and "villains" of the news were. At the same time media products are always polysemic, a term which denotes that they have multiple meanings and are thus open to a variety of interpretations. Although journalists framed 
stories in ways that suggested a particular narrative, readers might have chosen to authorize alternative interpretations. For example, a 1957 Christian Century series by Marcus Bach covered Unity, Baha'i, Jehovah's Witnesses, and Psychiana, a mail-order religion Frank Robinson founded in 1929. Many interested readers responded with letters asking how they could get in touch with the groups. Dismayed, managing editor Theodore Gill vehemently responded with an essay condemning all four movements as heretical (Gill 1957). As in that instance, what writers and editors want to communicate may not be what readers choose to receive.

\section{Conclusion: Do media influence perceptions of new religions?}

While it is hard to gauge how individual readers respond to journalistic accounts, media undoubtedly influence audience perceptions. Scholar Stuart Hall argues that "the mass media are more and more responsible (a) for providing the basis on which groups and classes construct an 'image' of the lives, meanings, practices and values of other groups and classes; (b) for providing the images, representations and ideas around which the social totality, composed of all these separate and fragmented pieces, can be coherently grasped as a "whole" (Hall 1979, 340). There is no doubt that television and national periodicals have established connections between certain characteristics and new religions that audiences have accepted. The contemporary association of the terms "cult" and "brainwashing" has been partly constructed and inculcated by American mass media. Since at least the late 1970, polls show that many Americans hold suspicious and even negative views of new religious groups. For example, a 1989 Gallup poll asserted that sixty-two percent of Americans would not want religious sects or cults as neighbors, twice as high as the second most disliked and almost equally pressbeaten category, fundamentalists (Richardson 1995, 162). A USA Today poll, conducted three days after the Branch Davidian standoff ended in flames, found that ninety-three percent blamed the tragic outcome solely on group leader David Koresh (Martin 1998, 12). Although one could never claim that mass media representations caused these unfavorable public responses, they certainly contributed by promoting negative, unnuanced images of the groups in question. Only time and research will tell if media "mainstreaming" of new religions, such as the example of Neopagan Wicca, will have a converse effect.

\section{Note}

*Correspondence address: Department of Religious Studies, The University of North Carolina at Charlotte, Charlotte, NC 28223, USA.

\section{References}

Barker, Eileen. "Cult and Anti-Cult Since Jonestown." Annual Review of Sociology (1986): 329-46. Beckford, James A. "The Mass Media and New Religious Movements." New Religious Movements: Challenge and Response. Eds. Bryan Wilson and Jamie Cresswell. New York: Routledge, 1999. 103-19. 
“'Black Supremacy' Cult in U.S. - How Much of a Threat?” U.S. News and World Report 9 Nov. 1959: 112-14.

Bromley, David G., and James T. Richardson, eds. The Brainwashing/Deprogramming Controversy: Sociological, Psychological, and Historical Perspectives. New York: Edwin Mellen Press, 1983.

Bromley, David G., and Anson Shupe, Jr. The New Vigilantes: Anti-Cultists, Deprogrammers, and the New Religions. Beverly Hills, CA: Sage, 1980.

- Strange Gods: The Great American Cult Scare. Boston, MA: Beacon Press, 1981.

Brossard, Chandler. "California's Offbeat Religions: 'We Love You.'” Look 29 Sep. 1959: 99-103.

Chidester, David. Salvation and Suicide: An Interpretation of Jim Jones, the Peoples Temple, and Jonestown. Bloomington, IN: Indiana University Press, 1988.

Cox, Harvey. "Deep Structures in the Study of New Religions." Understanding the New Religions. Eds. Jacob Needleman and George Baker. New York: Seabury Press, 1978. 122-30.

"Cult of the Occult." Newsweek 13 April 1970: 96-7.

Davis, David Brion. "Some Themes of Countersubversion: An Analysis of Anti-Masonic, Anti-Catholic, and Anti-Mormon Literature." The Mississippi Valley Historical Review 47 (Sep. 1960): 205-24.

Dawson, Lorne. Comprehending Cults: The Sociology of New Religious Movements. New York: Oxford University Press, 1998.

van Driel, Barend, and James T. Richardson. "Print Media Coverage of New Religious Movements: A Longitudinal Study." Journal of Communication 38 (Summer 1988): 37-61.

Englehardt, Tom. The End of Victory Culture: Cold War America and the Disillusioning of a Generation. Amherst, MA: University of Massachusetts Press, 1995.

Gaustad, Edwin, ed. A Documentary History of Religion in America to the Civil War, 2nd edn. Grand Rapids, MI: Eerdmans, 1993. 459-62 and 442-5.

Gill,Theodore. "The Judges and the Judged." Christian Century 1 May 1957: 551-2.

Greil, Arthur. "Sacred Claims: The 'Cult Controversy' as a Struggle over the Right to the Religious Label." Religion and the Social Order: The Issue of Authenticity in the Study of Religions. Eds. David G. Bromley and Lewis F. Carter. Greenwich, CN: Jai Press, 1996. 56-57.

Hall, John R. Gone From the Promised Land:Jonestown in American Cultural History. New Brunswick, NJ:Transaction, 1987.

Hall, Stuart. "Culture, Media, and the "Ideological Effect." " Mass Communication and Society. Eds. James Curran, Michael Gurevitch, and Janet Woolacott. Beverly Hills, CA: Sage, 1979. 315-48.

Jacobs, Ronald N. Race, Media, and the Crisis of Civil Society: From Watts to Rodney King. New York: Cambridge University Press, 2000.

Kobler, John. "Out for a Night at the Local Caldron." Saturday Evening Post 5 Nov. 1966: 76-8.

Lippert, Randy. "The Construction of Satanism as a Social Problem in Canada." Canadian Journal of Socoilogy 15 (1990): 417-39.

Maaga, Mary McCormick. Hearing the Voices of Jonestown: Putting a Human Face on an American Tragedy. Syracuse: Syracuse University Press, 1998.

"Mad About Moon." Time 10 Nov. 1975: 44.

Martin, Joel W. "Forum: Interpreting Waco." Religion and American Culture: A Journal of Interpretation Winter 1998: 8-17.

Mathison, Richard. Faiths, Cults, and Sects of America: from Atheism to Zen. Indianapolis: Bobbs-Merrill, 1960.

McCloud, Sean. Making the American Religious Fringe: Exotics, Subversives, and Journalists, 1955-93. Chapel Hill, NC: The University of North Carolina Press, 2004.

Melton, J. Gordon. "Anti-Cultists in the United States: An Historical Perspective." New Religious Movements: Challenge and Response. Eds. Bryan Wilson and Jamie Cresswell. New York: Routledge, 1999. 213-33.

Morrow, Lance. "In the Name of God." Time 15 Mar. 1993: 34.

"The New Rebel Cry: Jesus is Coming!" Time 21 Jun. 1971: 63.

"The Occult: A Substitute Faith." Time 19 Jun. 1972: 62-9.

Richardson, James T. "Definitions of Cult: From Sociological-Technical to Popular-Negative." Review of Religious Research 34 (1993): 348-56.

—. "A Critique of 'Brainwashing' Claims About New Religious Movements." Australian Religious Studies Review 7 (1994): 48-56. 
"Manufacturing Consent About Koresh: A Structural Analysis of the Role of Media in the Waco Tragedy." Armageddon in Waco: Critical Perspectives on the Branch Davidian Conflict. Ed. Stuart A. Wright. Chicago, IL:The University of Chicago Press, 1995. 153-76.

Richardson, James T., and Barend van Driel. "Journalists' Attitudes Toward New Religious Movements." Review of Religious Research 39 (Special Issue: Mass Media and Unconventional Religion, edited by Stuart A. Wright) (Dec. 1997): 116-36.

Robbins, Thomas. "Constructing Cultist 'Mind Control.", Sociological Analysis 45 (1984): 241-56.

Robinson, Louie. "The Kingdom of King Narcisse: California breeds another bizarre but colorful sect." Ebony 18 (Jul. 1963): 112.

Shupe, Anson. "Constructing Evil as a Social Process: The Unification Church and the Media." Uncivil Religion: Interreligious Hostility in America. Eds. Robert N. Bellah and Frederick E. Greenspahn. New York: Crossroad, 1987. 205-18.

—_. "Vicissitudes of Public Legitimacy for Religious Groups: A Comparison of the Unification and Roman Catholic Churches." Review of Religious Research 39 (Special Issue: Mass Media and Unconventional Religion, edited by Stuart A. Wright) (Dec. 1997): 172-83.

Shupe, Anson, and David G. Bromley. "The Modern North American Anti-Cult Movement 1971-91: A Twenty-Year Retrospective." Anti-Cult Movements in Cross-Cultural Perspective. Eds. Anson Shupe and David G. Bromley. New York: Garland Publishing, 1994. 3-31.

Victor, Jeffrey S. Satanic Panic: The Creation of a Contemporary Legend. Chicago, IL: Open Court, 1993.

“The Way of the Cults.” Newsweek 7 May 1956: 102, 105.

Wright, Stuart A. "Media Coverage of Unconventional Religion: Any 'Good News' for Minority Faiths?” Review of Religious Research 39 (Special Issue: Mass Media and Unconventional Religion, edited by Stuart A. Wright) (Dec. 1997): 101-15.

van Zuilen, J. The Life Cycle of Magazines: A Historical Study of the Decline and Fall of the General Interest Mass Audience Magazine in the United States During the Period 1946-1972. Uithoorn, The Netherlands: Graduate Press, 1977. 